Article

\title{
Life Cycle Assessment of Lubricant Oil Plastic Containers in Brazil
}

\author{
Maria Clara Oliveira * and Alessandra Magrini \\ Energy Planning Program, Graduate School of Engineering, Universidade Federal do Rio de Janeiro, \\ Centro de Tecnologia, bloco C, sala 211-Cidade Universitária, Ilha do Fundão, Rio de Janeiro RJ-21941-972, \\ Brazil; ale@ppe.ufrj.br \\ * Correspondence: mariaclarabrandt@gmail.com; Tel.: +55-21-992088992
}

Academic Editor: Matthias Finkbeiner

Received: 31 January 2017; Accepted: 6 April 2017; Published: 10 April 2017

\begin{abstract}
Brazil, like many emerging countries, has experienced a fast growth in the demand for automobiles in recent decades. This has produced a significant increase in the amount of hazardous waste to be disposed of, including used lubricant oil. Restrictive regulations are being used by many nations to deal with this problem, focusing on treatments, such as recycling, to avoid resource depletion. Specific rules for disposal of used lubricant oil already exist in various countries, including Brazil, but not for its containers. Using the life cycle assessment methodology, this article evaluates different management options for the destination of Lubricant Oil Plastic Containers (LOPCs), comparing recycling and incineration to disposal in an industrial landfill. Results show that reducing the proportion of LOPCs destined to the landfill has positive impacts in lowering the burdens caused in the life cycle of LOPCs. Incineration, which is not a technology used for destination of LOPCs in Brazil, proved to be a promising option when combined with recycling for treatment of this kind of waste. Combining different destinations is also a good option as long as economic, logistics and the environment are taken into consideration. The present paper concludes that emerging countries are able to manage hazardous waste provided that there is adequate legislation and political will along with cooperation from the private sector. This study can be helpful to the decision-making processes concerning hazardous waste, especially for industrial strategies and policy makers.
\end{abstract}

Keywords: reverse logistics; hazardous waste management; plastic packaging; life cycle assessment; recycling

\section{Introduction}

As observed in many emerging countries, Brazil has experienced exponential growth in the number of automobiles in the last decades. In 2014, the car fleet in Brazil was estimated to be around 35 million units, having risen more than $60 \%$ in the previous seven years [1]. This expansion puts more pressure on the already difficult problem of waste disposal that the country currently faces as it increases the amount of hazardous waste (and materials of difficult degradation, i.e., plastics, rubber and metals) being disposed of in landfills [2].

The rise in the number of vehicles has led to a higher consumption of maintenance and operational products, such as lubricant oil [3]. Around $56 \%$ of the total demand for this product comes from the automotive sector, and about $50 \%$ is lost in the process of combustion, through evaporation, remaining oil in the packaging, and so on. Most of the remainder of the used oil is collected and treated in the end-of-life stage [4,5].

As lubricant oils are a hazardous waste [6], their incorrect disposal causes serious environmental impacts, imposing risks to human health, air and water pollution [7]. According to Willing [8], one liter of used lubricant oil can contaminate one million liters of water, and its degradation can take 300 years. 
After being changed in a vehicle, 30-60 mL of lubricating oil still remains in the "empty" container. Therefore, the container itself is also considered hazardous waste and should be managed separately from other solid wastes [7]. Lubricant oil plastic containers (LOPCs) are made of high-density polyethylene (HDPE), one of the most consumed plastic resins in Europe and in Brazil $[9,10]$.

About 305 million lubricant oil containers are consumed each year in Brazil, in different sizes $(0.5 \mathrm{~L}, 1,3,4$ and $5 \mathrm{~L}, 10 \mathrm{~L}, 20 \mathrm{~L}, 200 \mathrm{~L}$ and $1000 \mathrm{~L})$, of which around $70 \%$ are plastic containers used for automotive oil, with the remaining $30 \%$ being metal barrels used for industrial oil [11]. LOPCs represent $2 \%$ of the total plastic packaging waste in the country [12].

The implementation of effective and sustainable waste management strategies is of paramount importance [13]. The problem in Brazil, as in other emerging countries, is that cost considerations have led to non-optimal solutions. Therefore, industrial landfills are the most used end-of-life destination for LOPCs, being preferred over other options such as recycling, incineration, or co-processing [14,15].

Specific legislation concerning the management of used lubricant oil already exists around the world. The Waste Framework Directive 2008/98/EC states that used lubricant oil management should focus on waste hierarchy [16]. Life cycle assessment studies have also concluded that re-refining is the best recovery option for lubricant oils because it causes less environmental impacts compared to other management options [17-19].

Frequently, used lubricant oil plastic containers (LOPCs) have been overlooked as a hazardous waste by policy makers [3]. Worldwide legislation regarding these containers is still very scarce or included as part of other directives, being seldom specific. Examples include the European Plastic and Packaging Waste Directive (94/62/EC) [20], which sets targets for recovering and recycling of waste packaging, the Waste Directive (2008/98/EC) [16], which has four articles on hazardous waste, and the American Resource Conservation and Recovery Act, which sets a framework for the management of hazardous waste [21].

In Brazil, the National Solid Waste Policy (PNRS in the Portuguese acronym) was enacted in 2010 (Law 12.305/10) [22], defining the tools and responsibilities for dealing with solid waste. The section about shared responsibilities between government and the private sector states that manufacturers, importers, distributors, retailers, and consumers are responsible for the life cycle of products, regardless of the already existing urban trash collection services or solid waste management services.

It also attributes to all agents the obligation to structure and implement reverse logistics systems for the correct disposal at the end of life of pesticides, their residues and packaging, batteries, tires, lubricant oils, their residues and packaging, lamps, electronic goods and their components.

Authors have defined reverse logistics in different ways [23-27]. The most widely accepted definition is given by Rogers and Tibben-Lembke [28] who describe reverse logistics as "the process of planning, implementing, and controlling the efficient, cost-effective flow of raw materials, in process inventory, finished goods, and related information from the point of consumption to the point of origin for the purpose of recapturing value or proper disposal". Reverse logistics is normally implemented for waste management and material/product recovery through recycling or remanufacturing [29]. The key steps are acquisition of used products, collection, sorting/separation and destination [30].

Acting in accordance with the PNRS, Brazilian producers and sellers of lubricant oil signed an agreement with the Government for the implementation of a system of reverse logistics of lubricant oil plastic containers, pledging to cover the whole country by the end of 2016. Unfortunately, this has not yet happened, and the proportion of used LOPCs collected and recycled is still low, comprising around $16 \%$ of the total.

Although there is an organization called Instituto Jogue Limpo [31] responsible for dealing with this kind of residue, it still encompasses neither the whole country, nor all the establishments that sell/change lubricant oil. They face the same problems and barriers that other companies face when dealing with reverse logistics, which include lack of financial incentives and personnel resources (staff must be trained to deal with hazardous waste) [28]. 
The PNRS states that the preferred treatment for LOPCs is recycling, which has been the only treatment used until now. However, this procedure has not always been feasible due to lack of recycling facilities. This problem is aggravated in countries as large as Brazil, in which long distances from collection to recycling facilities entail high transportation costs and additional emissions of greenhouse gases [32]. The LOPCs that do not undergo recycling are disposed in industrial landfills.

Even though incineration (waste-to-energy) is still not a common treatment option in Brazil [33-35], in Europe it is the most-used treatment for hazardous waste [7], therefore it should also be considered in this analysis as an option for the final destination of used LOPCs.

Different assessments and methods for studying and describing environmental and sustainability performance have been developed over the past years. Life Cycle Assessment (LCA) is the most popular and globally-accepted system assessment tool for dealing with waste management, also being a well-established environmental management tool [18,36].

LCA is a technique used to evaluate environmental impacts during the life cycle of a product, service or process $[37,38]$. Some LCA studies deal with integrated waste management systems as a whole, while others, such as the one presented in this article, focus on one single waste fraction [39]. The framework and methodology to develop a life cycle study are described by the ISO 14040 and 14044 standards [40,41], but also by Guinèe et al. [42] and the International Reference Life Cycle Data System (ILCD) handbook series [43] by the environmental department of the Joint Research Center of the European Commission.

The interest in LCA is growing and every year more researchers are using this method. Although many publications have focused on plastics and packaging (there are a several studies on LCA of plastics and plastic packaging, comparing environmental performance of different products [44-46], applications [47,48], types of plastic [49], and end-of-life treatment options [50-52]), thus far no specific studies were found using LCA as a tool to address the management of lubricant oil plastic containers.

This study may provide input into further investigations on hazardous waste management as well as useful elements to expand the already existing waste management and recycling programs.

In the present paper, life cycle assessment is used as a management tool to evaluate the life cycle of lubricating oil plastic containers, comparing the current practice-recycling-to incineration with energy generation (waste-to-energy), which is a treatment widely used in many countries, as alternative options to industrial landfilling. Due to the difficulties of analyzing the whole country, a case study was carried out in the State of Rio de Janeiro which was chosen for having both a large population and a massive fleet of vehicles [1,53]. With 16 million inhabitants, Rio de Janeiro is the third most populated state in Brazil and its number of light vehicles is estimated to be over 6 million units. Its demand for lubricant oil in 2014 was around 118 million tonnes [11].

\section{Materials and Methods}

LCA studies in emerging countries are many times hindered by the lack of reliable information. Their success depends on the amount and quality of the information collected, especially local data, the knowledge of the technology applied, and simplifications and approaches used [42]. Case studies are a good option for gathering primary data and qualitative and quantitative information [54]. Willers and Rodrigues [55] state that there are many possible applications for LCA studies in Brazil due to its economic profile, and Zanghelini et al. [56] affirm that the assessment of industrial sectors is fundamental for achieving environmental goals in the country.

The ISO 14040 and 14044 standards provide the principles and frameworks for the conduction of LCA studies [40,41]. They distinguish four phases of a life cycle assessment: (a) goal and scope definition, (b) inventory analysis including the inputs and outputs of the system flows, (c) impact assessment including the evaluation of the effects on human health and the environment, and $(\mathrm{d})$ interpretation of the results. 


\subsection{Goal and Scope}

The goal of this study is to evaluate the different impacts associated with the life cycle of LOPCs. This includes different management options for the end-of-life of LOPCs that can be used in the future decision-making process.

A LCA study can have an attributional or consequential approach, according to the ILCD Handbook [43]. Attributional modeling is used for existing supply-chains, whereas the consequential approach models generic inputs and outputs expected as a consequence of possible decisions made in the system background. To identify the most appropriate impact assessment modeling and method to comply with the goal and scope of the work, an LCA should be carried out following one of three different context situations: A (micro-level, no large-scale consequences), B (macro-level, strategic/large-scale consequences) or C (accounting-type of life cycle model) [43]. The attributional approach was considered more appropriate for the purpose of this analysis as it reflects the real situation of the processes and the life cycle of the analyzed system. Considering that this is a product-based study, it fits situation A (micro-level decision support).

\subsubsection{Functional Unit}

The functional unit (FU) quantifies the performance of a product system and gives a reference for the input and output flows in a life cycle assessment study. The FU used was one tonne of high-density polyethylene (HDPE), as it can be applied to the whole chain.

\subsubsection{Description of Scenarios and System Boundaries}

In order to study the life cycle of LOPCs, the analysis considers their production, distribution in the state of Rio de Janeiro, collection and final destination, including reverse logistics for recycling and incineration. The scope of this study encompasses the impacts caused and avoided through these different stages.

One producer/actor was chosen for each step of the case study. The production of LOPCs takes place in a factory located in a small town about $250 \mathrm{~km}$ from the city of Rio de Janeiro, in the state which is its namesake. Once a week, the oil company sends a lorry (medium weight, $7.5-16$ tonnes) with virgin HDPE pellets and collects the new containers to be filled with oil and distributed. The HDPE pellets are extruded with the pigment, and a material balance is considered in the process. Water is used for cooling the plastic when entering the machine $\left(25^{\circ} \mathrm{C}\right)$ and after molding $\left(15^{\circ} \mathrm{C}\right)$. The oil company is responsible for the supply of $30 \%$ of the market in the state of Rio de Janeiro (heavy weight lorries, $>28$ tonnes) (Figure 1).

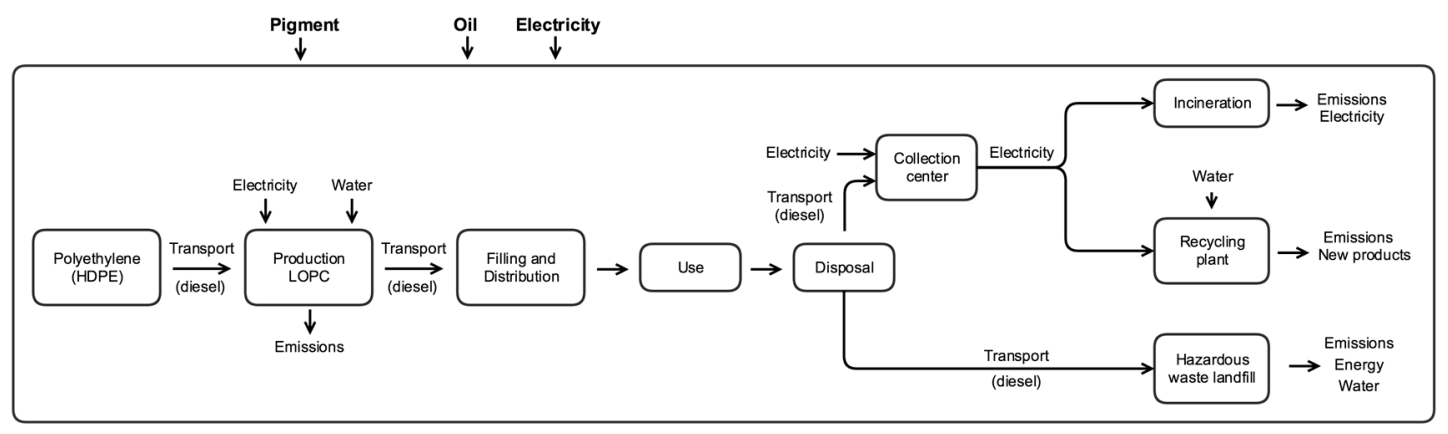

Figure 1. Life cycle of LOPCs with different disposal options.

After lube oil changes, mostly done at service stations and repair shops, the LOPCs are stored for disposal. Final destination options can be an industrial landfill, a recycling plant, or an incinerator. Using a reverse logistic system, the Instituto Jogue Limpo collects the used containers for recycling. 
There is just one company authorized to perform this reverse logistics process in the state of Rio de Janeiro with skilled professionals trained to deal with hazardous materials. They collect the empty containers with lorries (light weight, 3.5-7.5 tonnes; $20,000 \mathrm{~km} / \mathrm{month}$ ), equipped with a scale and scanners. The LOPCs are taken to the collection center, where they are sorted and kept upside down to eliminate as much oil as possible. Afterwards, they pass through a granulator machine to create pellets and are stored in big bags. Another company is hired to take the trimmed HDPE to the recycling plant (heavy weight lorries, $>28$ tonnes).

In the recycling plant, the pellets are melted and extruded to be transformed into new products; in this case, corrugated pipes. In other words, it is an open-loop recycling process. The technology used does not require the plastic to be washed beforehand, but water is used for cooling the new product. The remaining oil is incorporated into the new product without impairing its quality.

The industrial landfill that accepts this kind of waste is located in a state to the northern border of Rio de Janeiro, called Espírito Santo. The LOPCs are first stored in a facility in the state of Rio de Janeiro, with no extra processing to eliminate the remaining oil. When there are enough to fill a lorry (heavy weight, $>28$ tonnes), the load is sent over a distance of $490 \mathrm{~km}$ to be landfilled. When plastic is landfilled, it is assumed that no emissions are generated (Syke, [57]).

For the hypothetical alternative of incineration (waste-to-energy), the LOPCs are collected and transported to a collection center, as in the recycling case, and then transported to an incinerator facility, which is an existing hazardous waste incineration plant, though it does not process LOPCs, $32 \mathrm{~km}$ away, in the city of Rio de Janeiro (heavy weight lorry, $>28$ tonnes). The LOPCs are considered to be completely incinerated at a rotatory kiln incinerator, adapted for the treatment of hazardous waste, and with a capacity of processing 456 tonnes of waste per month (installed capacity of the incinerator). The ashes and emissions were considered for the study, but not the transportation of the ashes to a treatment/disposal facility. It was considered that the incineration process generates energy, and inventory data was calculated based on the Intergovernmental Panel on Climate Change (IPCC) [7], the national inventory [58] and on data from a European hazardous waste incinerator [59].

Different waste treatment scenarios were created following the waste hierarchy. Recycling and incineration were prioritized, followed by industrial landfilling as last option. Even though incineration is not currently applied as a technology for treatment of this kind of waste in Brazil, two scenarios were created using it as a possible option for destination of LOPCs.

The alternative scenarios under study are:

- Scenario 0: Recycling 16\%, industrial landfill $84 \%$ (current situation)

- Scenario 1: Recycling 50\%, industrial landfill 50\%

- Scenario 2: Recycling 16\%, incineration $16 \%$, industrial landfill $68 \%$

- Scenario 3: Recycling 50\%, incineration 50\%

The hypotheses assume that the recycling comprises the production of different products (open-loop) and the incineration is used for energy generation, to be supplied to the Brazilian grid.

The boundaries of the system include only the LOPCs themselves, excluding the caps/bottle tops and the bags in which the used containers are stored for transportation. Data about the filling of the containers with lubricant oil were also not included.

The LOPCs disposal options examined generate several co-products that are substitutes for the products / fuels produced through conventional technology, such as recycled material, electric energy and energy heat. HDPE substitutes virgin plastic with a ratio of 1:1, assuming that there are neither losses nor degradation in the process of recycling. For the energy, the substitution rate is also of 1:1.

\subsection{Life Cycle Inventory}

In any life cycle study, the life cycle inventory is a crucial stage, because that is when specifications of the data collected are checked, in accordance with the ISO 14040 standards [40]. 
The data assembly was carried out mainly through direct interviews and primary data gathering. Whenever primary data was not available, information in the literature and the Ecoinvent [60] database were used. Inputs and outputs on production of polyethylene and diesel for transport were compiled from an important Brazilian company and the national emissions inventory [58], respectively. Emissions were calculated based on the conversion factors [61] presented in Table 1. Regarding electricity, the Brazilian medium voltage mix was used (data from Ecoinvent).

Data on the production and distribution of LOPCs was provided by a producer of this plastic packaging and by one of the largest lube oil producers and distributers in Brazil (in order to preserve the companies' identities and data privacy, their names will not be revealed), respectively. The Instituto Jogue Limpo also provided valuable input for the development of the present work, including data on collection of used LOPCs and demand for diesel and electricity.

Information regarding water, transportation, energy and heat was obtained directly in the recycling plant. Table 2 presents the inputs and outputs of the LOPC life cycle.

Table 1. Conversion factors in $\mathrm{g} / \mathrm{kg}$ of diesel [58].

\begin{tabular}{cccc}
\hline Type of Emission & $\begin{array}{c}\text { Light Weight Lorry, } \\
\text { 3.5-7.5 Tonnes }\end{array}$ & $\begin{array}{c}\text { Medium Weight Lorry, } \\
\mathbf{7 . 5 - 1 6} \text { Tonnes }\end{array}$ & $\begin{array}{c}\text { Heavy Weight Truck, } \\
\text { >28 Tonnes }\end{array}$ \\
\hline $\mathrm{CO}_{2}$ & 2.7 & 2.7 & 2.7 \\
$\mathrm{CO}$ & 0.42 & 0.58 & 1.01 \\
$\mathrm{NO}_{\mathrm{x}}$ & 0.08 & 0.11 & 0.19 \\
$\mathrm{PM}$ & 0.04 & 0.054 & 0.095 \\
$\mathrm{NMVOC}$ & 2.37 & 3.25 & 5.68 \\
\hline
\end{tabular}

PM: particulate matter; NMVOC: Non-methane volatile organic compounds.

Table 2. Inventory data for the inputs and outputs of the life cycle of Lubricant Oil Plastic Containers (LOPC).

\begin{tabular}{|c|c|c|c|c|c|}
\hline \multicolumn{3}{|c|}{ Input } & \multicolumn{3}{|c|}{ Output } \\
\hline \multicolumn{6}{|c|}{ Production LOPC } \\
\hline Material & Amount & Units & Material & Amount & Units \\
\hline HDPE & 1 & tonne & LOPC & 1 & tonne \\
\hline Diesel (transport) & 63.75 & $\mathrm{~L}$ & Heat & $6.14 \times 10^{3}$ & MJ \\
\hline Energy & 52,500 & $\mathrm{kWh}$ & $\mathrm{CO}_{2}$ & 172,125 & $\mathrm{~kg}$ \\
\hline \multirow{4}{*}{ Water (cooling) } & 2.99 & $\mathrm{~m}^{3}$ & $\mathrm{CO}$ & 0.023562 & $\mathrm{~kg}$ \\
\hline & & & PM & 2.244 & $\mathrm{~kg}$ \\
\hline & & & $\mathrm{NO}_{\mathrm{x}}$ & $4.488 \times 10^{3}$ & $\mathrm{~kg}$ \\
\hline & & & NMVOC & 132.957 & $\mathrm{~kg}$ \\
\hline \multicolumn{6}{|c|}{ Distribution } \\
\hline LOPC & 1 & tonne & $\mathrm{CO}_{2}$ & $6.102 \times 10^{3}$ & $\mathrm{~kg}$ \\
\hline Diesel (transport) & 2.26 & $\mathrm{~L}$ & $\mathrm{CO}$ & $1.15 \times 10^{-6}$ & $\mathrm{~kg}$ \\
\hline \multirow{3}{*}{ Lubricant oil * } & 43 & tonnes & PM & $1.074 \times 10^{-4}$ & $\mathrm{~kg}$ \\
\hline & & & $\mathrm{NO}_{\mathrm{x}}$ & $2.19 \times 10^{-1}$ & $\mathrm{~kg}$ \\
\hline & & & NMVOC & $6.46 \times 10^{-3}$ & $\mathrm{~kg}$ \\
\hline \multicolumn{6}{|c|}{ Collection LOPC (Instituto Jogue Limpo) } \\
\hline LOPC & 1 & tonne & HDPE & 1 & tonne \\
\hline Diesel (transport) & 69.92 & $\mathrm{~L}$ & $\mathrm{CO}_{2}$ & $1.88 \times 10^{2}$ & $\mathrm{~kg}$ \\
\hline Energy & $1.080 \times 10^{3}$ & $\mathrm{kWh}$ & $\mathrm{CO}$ & $2.58 \times 10^{-2}$ & $\mathrm{~kg}$ \\
\hline \multirow[t]{3}{*}{ Lubricant oil * } & 1.935 & tonnes & PM & $2.46 \times 10^{-3}$ & $\mathrm{~kg}$ \\
\hline & & & $\mathrm{NO}_{\mathrm{x}}$ & $4.92 \times 10^{-3}$ & $\mathrm{~kg}$ \\
\hline & & & NMVOC & $1.46 \times 10^{-1}$ & $\mathrm{~kg}$ \\
\hline
\end{tabular}


Table 2. Cont.

\begin{tabular}{|c|c|c|c|c|c|}
\hline \multicolumn{3}{|c|}{ Input } & \multicolumn{3}{|c|}{ Output } \\
\hline \multicolumn{6}{|c|}{ Production LOPC } \\
\hline Material & Amount & Units & Material & Amount & Units \\
\hline \multicolumn{6}{|c|}{ Recycling LOPC } \\
\hline HDPE & 1 & tonne & Product & 1 & tonne \\
\hline Diesel (transport) & 0.387 & $\mathrm{~L}$ & Heat & $1.83 \times 10^{3}$ & MJ \\
\hline Energy & 13,305 & $\mathrm{kWh}$ & $\mathrm{CO}_{2}$ & $1.045 \times 10^{4}$ & $\mathrm{~kg}$ \\
\hline \multirow[t]{4}{*}{ Water (cooling) } & 19.7 & $\mathrm{~m}^{3}$ & $\mathrm{CO}$ & $3.44 \times 10^{-4}$ & $\mathrm{~kg}$ \\
\hline & & & PM & $3.24 \times 10^{-5}$ & $\mathrm{~kg}$ \\
\hline & & & $\mathrm{NO}_{\mathrm{x}}$ & $6.47 \times 10^{-5}$ & $\mathrm{~kg}$ \\
\hline & & & NMVOC & $1.93 \times 10^{-3}$ & $\mathrm{Kg}$ \\
\hline
\end{tabular}

\begin{tabular}{cccccc}
\hline \multicolumn{5}{c}{ Incineration } \\
\hline HDPE & 1 & tonne & Ash & 0.01 & tonne \\
Diesel (transport) & 21.8 & $\mathrm{~L}$ & Heat & $1087 \times 10^{3}$ & $\mathrm{MJ}$ \\
Energy & 500 & $\mathrm{kWh}$ & $\mathrm{CO}_{2}$ & 58.86 & $\mathrm{~kg}$ \\
Heating oil & 0.008095 & tonne & $\mathrm{CO}$ & $1.94 \times 10^{-2}$ & $\mathrm{~kg}$ \\
Natural gas & 0.963657 & $\mathrm{GJ}$ & $\mathrm{PM}$ & $1.82 \times 10^{-3}$ & $\mathrm{~kg}$ \\
Water & 3581 & $\mathrm{~L}$ & $\mathrm{NO}$ & $3.64 \times 10^{-3}$ & $\mathrm{~kg}$ \\
& & & NMVOC & $1.09 \times 10^{-1}$ & $\mathrm{~kg}$ \\
& & & Water & 1098 & $\mathrm{~L}$ \\
\hline
\end{tabular}

\begin{tabular}{|c|c|c|c|c|c|}
\hline \multicolumn{6}{|c|}{ Industrial Landfill } \\
\hline HDPE & 1 & tonne & $\mathrm{CO}_{2}$ & 187.866 & $\mathrm{~kg}$ \\
\hline Diesel (transport) & 69.58 & $\mathrm{~L}$ & $\mathrm{CO}$ & $3.45 \times 10^{-2}$ & $\mathrm{~kg}$ \\
\hline Energy & 0.367 & kWh & PM & $3.66 \times 10^{-3}$ & $\mathrm{~kg}$ \\
\hline \multirow[t]{3}{*}{ Lubricant oil } & 1.935 & tonnes & $\mathrm{NO}_{\mathrm{x}}$ & $7.01 \times 10^{-3}$ & $\mathrm{~kg}$ \\
\hline & & & NMVOC & $2.08 \times 10^{-1}$ & $\mathrm{~kg}$ \\
\hline & & & Heat & 32.9 & GJ \\
\hline
\end{tabular}

* Lubricant oil used for calculation of weight for transportation only, considering that $45 \mathrm{~mL}$ oil remains in the "empty" bottle. The density of lubricant oil is $0.86 \mathrm{~g} / \mathrm{cm}^{3}$ [62]. HDPE: high-density polyethylene.

\section{Life Cycle Impact Assessment}

The life cycle impact assessment (LCIA) was performed using SimaPro 8.1.1.16 software (PRé-Consultants: Amersfoort, The Netherlands), and the method selected was the ReCiPe 2008 midpoint (Goedkoop et al., [63]). The ReCiPe methodology integrates midpoint and endpoint approaches, which are both characterization methods with indicators at different levels. The first evaluates the environmental impact at a level in the cause-effect chain, and the latter at the areas of protection (human health, ecosystems and resources) [43]. SimaPro is one of the leading software programs used for LCA studies, developed by PRè Consultants [64]. ReCiPe 2008 has been adopted worldwide, with uncertainty at the midpoint level results considered to be relatively low [65]. Furthermore, it is the LCIA method with the highest number of midpoint impact categories (eighteen), enabling a more consistent and complete analysis of the cases being studied. The impact categories selected were: climate change (CC), ozone depletion (OD), human toxicity (HT), photochemical oxidant formation (POF), particulate matter formation (PMF), ionizing radiation (IR), terrestrial acidification (TA), freshwater eutrophication (FE), marine eutrophication (ME), terrestrial ecotoxicity (TET), freshwater ecotoxicity (FET), marine ecotoxicity (MET), agricultural land occupation (ALO), urban land occupation (ULO), natural land transformation (NLT), metal depletion (MD) and fossil depletion (FD).

The results of the LCIA were normalized by applying the European normalization data for the year 2000 encompassed in the ReCiPe midpoint method, which is based on the report of Seleesjik et al., 2007 [66]. The normalization factors were: CC: $8.91 \times 10^{-5}$; OD: $4.54 \times 10^{1}$; HT: $1.69 \times 10^{-3}$; POF: $1.89 \times 10^{-2}$; PMF: $6.71 \times 10^{-2}$; IR: $1.60 \times 10^{-4}$; TA: $2.91 \times 10^{-2}$; FE: $2.41 \times 10^{0}$; ME: $9.88 \times 10^{-2}$; TET: 
$1.22 \times 10^{-1}$; FET: $9.19 \times 10^{-2}$; MET: $1.18 \times 10^{-2}$; ALO: $2.21 \times 10^{-4}$; ULO: $2.46 \times 10^{-3}$; NLT: $6.20 \times 10^{0}$; MD: $1.40 \times 10^{-3}$; FD: $6.14 \times 10^{-4}$. This step is used in LCAs to show the relative contribution of each environmental impact category to a reference situation, making it easier to compare the different categories.

\subsection{Sensitivity Analysis}

A sensitivity analysis was conducted to address uncertainties in this LCA study. Two parameters were changed to evaluate their influences on the environmental impact results: (1) The amount of lubricant oil that remains in the "empty" LOPCs was changed to both $30 \mathrm{~mL}$ and $60 \mathrm{~mL}$ to compare the impacts with those produced by the $45 \mathrm{~mL}$ baseline; and (2) The amount of HDPE that goes to the recycling or incineration plants was changed from $100 \%$ to $95 \%$ and $90 \%$, as the weighting of the material collected occurs before the separation of possible contaminants, such as other solid wastes that are thrown by mistake in the bins for disposal of used LOPCs.

\section{Results}

\subsection{Environmental Impacts of the Four Scenarios}

Table 3 presents the aggregated net values of the selected impact categories for the four proposed scenarios. Positive values represent environmental impacts (costs/burdens to the environment), whereas negative values show environmental benefits.

Table 3. LOPC impact assessment for the four scenarios proposed.

\begin{tabular}{cccccc}
\hline Impact Category & Abbr. & Scenario 0 & Scenario 1 & Scenario 2 & Scenario 3 \\
\hline Climate change & CC & $2.61 \times 10^{3}$ & $9.11 \times 10^{2}$ & $2.95 \times 10^{3}$ & $1.98 \times 10^{3}$ \\
Ozone depletion & OD & $1.16 \times 10^{2}$ & $5.90 \times 10^{1}$ & $1.16 \times 10^{2}$ & $5.80 \times 10^{2}$ \\
Human toxicity & HT & $4.97 \times 10^{4}$ & $2.87 \times 10^{4}$ & $4.10 \times 10^{4}$ & $1.47 \times 10^{3}$ \\
Photochemical oxidant formation & POF & $1.04 \times 10^{3}$ & $3.94 \times 10^{2}$ & $1.08 \times 10^{3}$ & $5.20 \times 10^{2}$ \\
Particulate matter formation & PMF & $1.48 \times 10^{3}$ & $6.21 \times 10^{2}$ & $1.47 \times 10^{3}$ & $5.96 \times 10^{2}$ \\
Ionizing radiation & IR & $5.71 \times 10^{2}$ & $2.16 \times 10^{2}$ & $5.91 \times 10^{2}$ & $2.78 \times 10^{2}$ \\
Terrestrial acidification & TA & $1.65 \times 10^{3}$ & $6.67 \times 10^{2}$ & $1.62 \times 10^{3}$ & $5.99 \times 10^{2}$ \\
Freshwater eutrophication & FE & $6.93 \times 10^{3}$ & $3.00 \times 10^{3}$ & $6.54 \times 10^{3}$ & $1.81 \times 10^{3}$ \\
Marine eutrophication & ME & $7.18 \times 10^{2}$ & $3.82 \times 10^{2}$ & $6.25 \times 10^{2}$ & $9.10 \times 10^{1}$ \\
Terrestrial ecotoxicity & TET & $9.22 \times 10^{2}$ & $4.15 \times 10^{2}$ & $8.46 \times 10^{2}$ & $1.75 \times 10^{2}$ \\
Freshwater ecotoxicity & FET & $2.37 \times 10^{5}$ & $1.40 \times 10^{5}$ & $1.93 \times 10^{5}$ & $2.19 \times 10^{3}$ \\
Marine ecotoxicity & MET & $3.10 \times 10^{5}$ & $1.84 \times 10^{5}$ & $2.52 \times 10^{5}$ & $2.65 \times 10^{3}$ \\
Agricultural land occupation & ALO & $3.37 \times 10^{2}$ & $1.68 \times 10^{2}$ & $2.99 \times 10^{2}$ & $5.1 \times 10^{0}$ \\
Urban land occupation & ULO & $1.69 \times 10^{2}$ & $8.20 \times 10^{1}$ & $1.55 \times 10^{2}$ & $4.00 \times 10^{0}$ \\
Natural land transformation & NLT & $1.75 \times 10^{5}$ & $7.44 \times 10^{4}$ & $1.69 \times 10^{5}$ & $5.48 \times 10^{4}$ \\
Metal depletion & MD & $2.15 \times 10^{3}$ & $1.12 \times 10^{3}$ & $1.87 \times 10^{3}$ & $2.65 \times 10^{2}$ \\
Fossil depletion & FD & $4.65 \times 10^{3}$ & $2.40 \times 10^{3}$ & $4.42 \times 10^{3}$ & $1.67 \times 10^{3}$ \\
\hline
\end{tabular}

Figure 2 shows this same data graphically, making it easier to analyze the results. It is possible to see, for example, that the highest impact is associated with MET, followed by FET, NLT and HT for all scenarios.

Scenario 0 is the one with the highest values, followed by Scenario 2 . These two scenarios have the greatest amounts of LOPCs being sent to landfills. Scenario 2 shows a reduction of these impacts, which results from raising recycling rates from 16 to $50 \%$. Scenario 3 presents much lower values for the impacts on human toxicity, freshwater toxicity and marine ecotoxicity than all the other scenarios. Its impact on natural land transformation was higher than the ones previously mentioned, although less significant than the results observed in the other scenarios. This is a scenario in which all LOPCs collected are sent only to recycling and incineration (waste-to-energy).

As mentioned previously, the numbers presented in Table 3 and Figure 2 are the net values of the impact assessment, which are the sum of the positive and negative values for each impact category 
evaluated. Impacts can have different values depending on the phase of the life cycle as some fluxes can cause burdens while others can avoid them. Figures 3-6 show the separate positive and negative gross values of the impact categories for each of the four scenarios.

In Scenario 0, the most relevant impacts in descending order of importance are related to marine ecotoxicity, freshwater ecotoxicity, natural land transformation and human toxicity. Positive values at a much lower level can also be observed in relation to fossil depletion, freshwater eutrophication, climate change, particulate matter formation, terrestrial acidification and mineral depletion. Avoided burdens for ionizing radiation and climate change are also present, but with low intensity, as can be observed in Figure 3.

Figure 4 demonstrates the impacts for Scenario 1. The ones that stand out are marine ecotoxicity, natural land transformation and freshwater ecotoxicity, in that order of intensity, with human toxicity standing a bit lower. Other impacts that should be mentioned for having positive values are climate change, freshwater eutrophication, metal depletion and fossil depletion. In this scenario, recycling was raised from $16 \%$ to $50 \%$, which explains the negative values of CC, POF, PMF, IR, TA and FE.

Figure 5 shows the same pattern as Figure 3, with the highest impacts being associated with MET, FET and NLT, respectively, followed by HT with a lower value. All other impact categories have positive results much lower than those four. The only burden avoided associated with Scenario 2 is NLT, but with a very low value.

Figure 6 reveals a different pattern from the previous ones, as the only impact category that really stands out is natural land transformation, with both high positive and negative values. Scenario 3 is the only one that does not have an industrial landfill as a destination option. In this case LOPCs, are diverted half and half to recycling and incineration (waste-to-energy). The other positive impacts observed are associated with CC, HT, FE, FET and MET., and burdens associated with CC, HT, POF, PMF, IR, TA, FE and MET decrease slightly.

Other results may be highlighted besides the net impacts already mentioned and presented in Figure 2. It is possible to see environmental impacts caused on climate change, freshwater eutrophication and fossil resources depletion for all four scenarios. Burdens avoided can be mainly observed in Scenario 1 on climate change and freshwater ecotoxicity and in Scenario 3 on natural land transformation, human toxicity, freshwater eutrophication, freshwater ecotoxicity, marine ecotoxicity and on natural land transformation. These are the scenarios with higher recycling rates and scenario 3 is the one with the highest incineration rate.

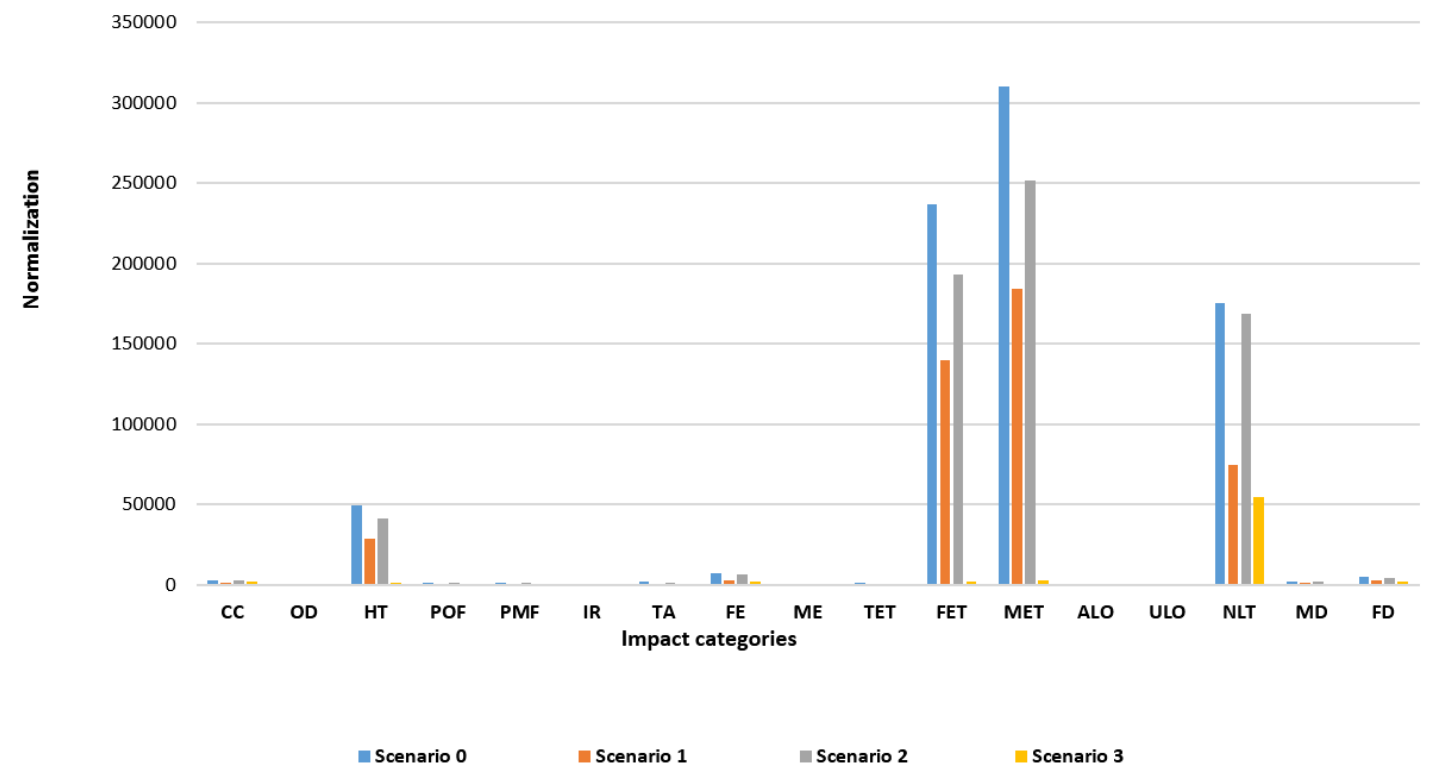

Figure 2. Graphic comparing the impact assessment of the 4 scenarios proposed. 


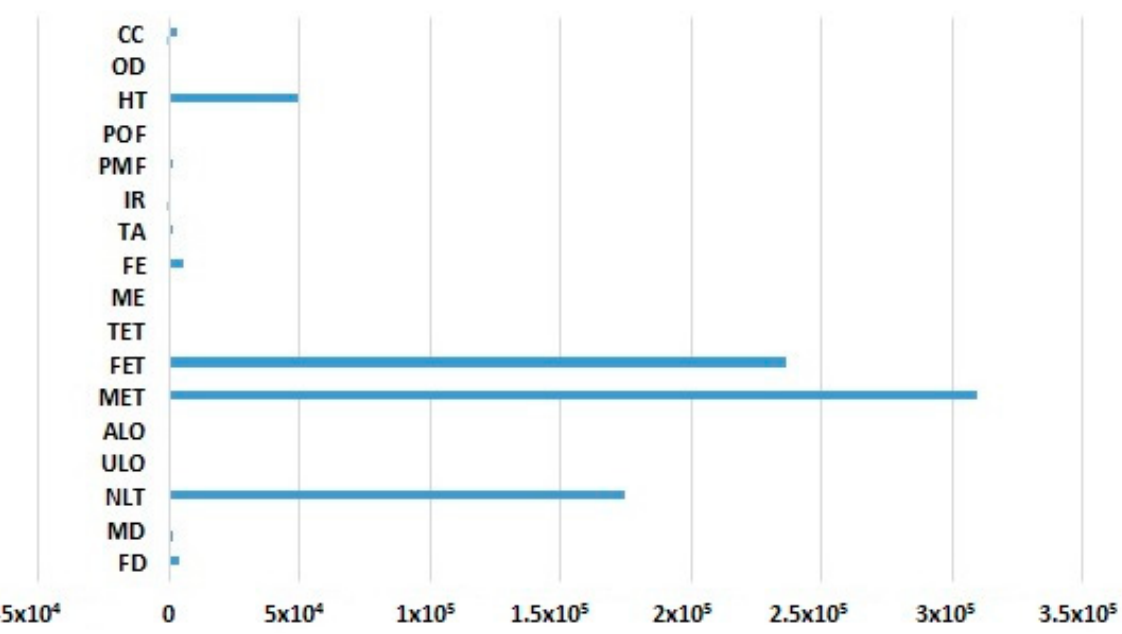

Figure 3. Graphic showing the positive and negative impacts associated with Scenario 0.

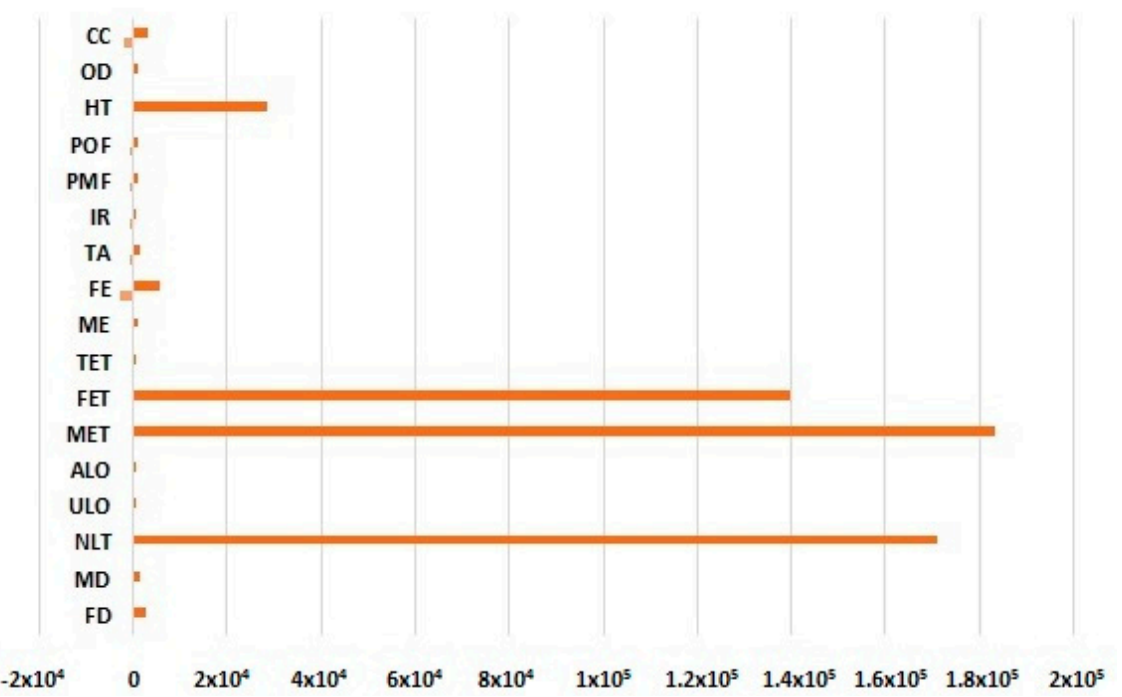

Figure 4. Graphic showing the positive and negative impacts associated with Scenario 1.

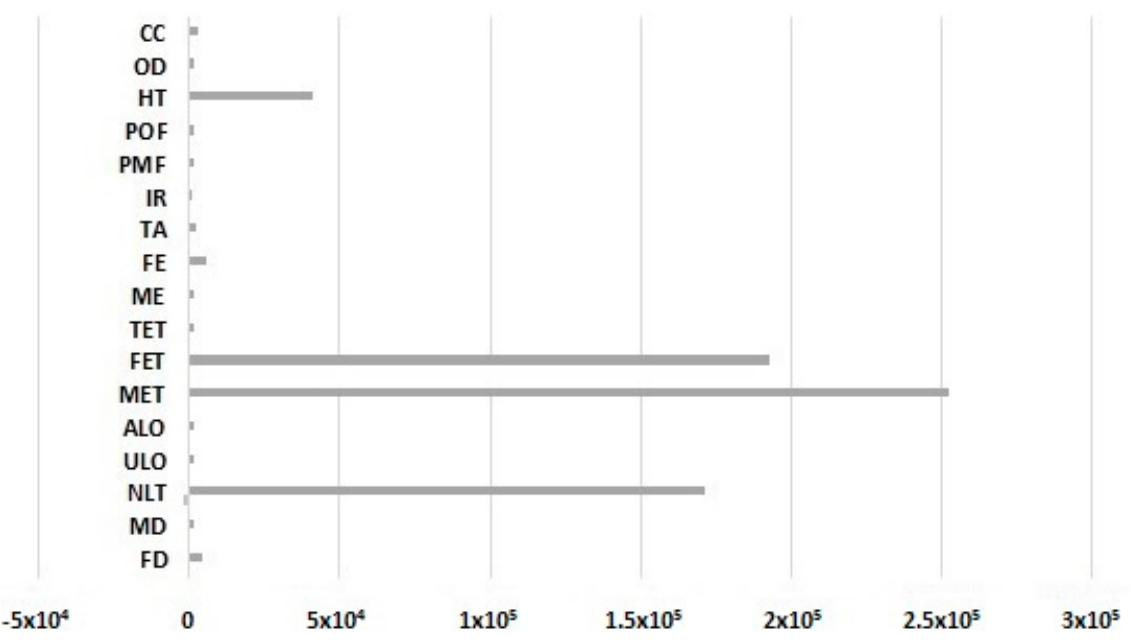

Figure 5. Graphic showing the positive and negative impacts associated with Scenario 2. 


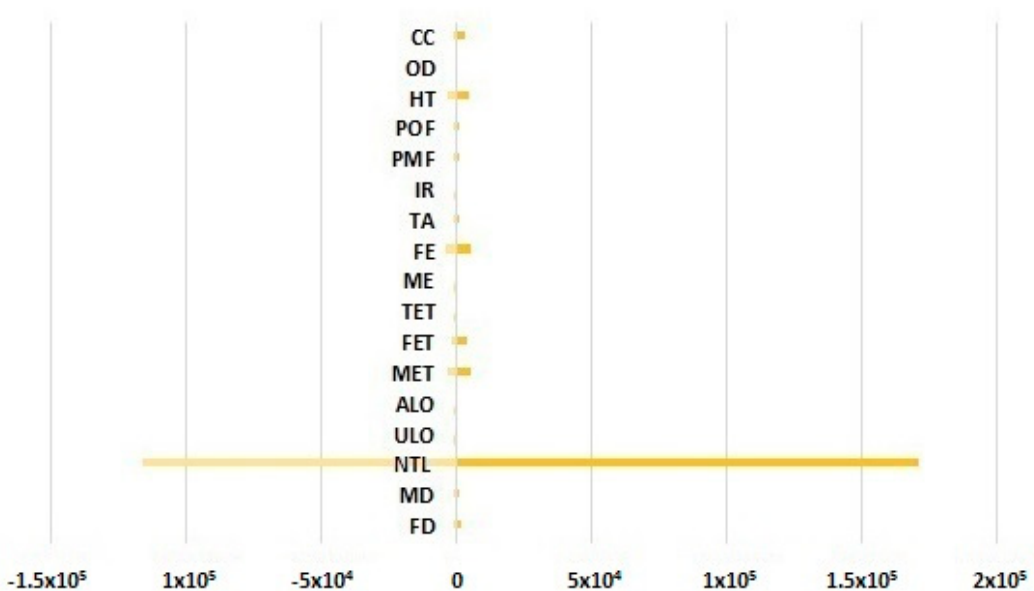

Figure 6. Graphic showing the positive and negative impacts associated with Scenario 3.

\subsection{Sensitivity Analysis Results}

When the amount of recycled or incinerated HDPE changed, Scenario 1 showed variations of up to 33\% for CC and Scenario 3 showed variations of up to 37\% for TE when there was less HDPE to be treated $(90 \%)$. Most of the impact categories were affected, which demonstrates that this parameter influences the overall results of the study (Table 4).

Table 5 shows that the variation of the amount of residual lubricant oil in LOPCs had considerable impact on Scenarios 0, 1 and 2 for the OD, TA, FD, ULO and NLT categories. Its effect was very low in Scenario 3, showing that this variation has a greater impact on scenarios that include industrial landfills as a destination option for LOPCs.

The sensitivity analysis demonstrates that both the amount of oil remaining in the LOPCs and the quantity of HDPE that goes to recycling or incineration can influence the final impacts caused by the life cycle of LOPCs, showing that more detailed data provides more accurate results, though it should be stressed that this does not change the overall conclusions of this study.

Table 4. Changes in parameters observed on the sensitivity analysis for the variation in amount of HDPE that goes to the recycling or incineration facilities.

\begin{tabular}{cccccc}
\hline Impact Categories & Abbr. & Scenario 0 & Scenario 1 & Scenario 2 & Scenario 3 \\
\hline Climate change & CC & $2-3 \%$ & $16-33 \%$ & $1-2 \%$ & $8-15 \%$ \\
Ozone Depletion & OD & $2 \%$ & $4-9 \%$ & $0-1 \%$ & $5-9 \%$ \\
Human Toxicity & HT & $0 \%$ & $1-2 \%$ & $0 \%$ & $16-31 \%$ \\
Photochemical Oxidant Formation & POF & $1-3 \%$ & $12-24 \%$ & $1-3 \%$ & $9-18 \%$ \\
Particulate Matter Formation & PMF & $1-3 \%$ & $9-18 \%$ & $1-3 \%$ & $9-18 \%$ \\
Ionizing Radiation & IR & $2-4 \%$ & $16-31 \%$ & $2-4 \%$ & $12-24 \%$ \\
Terrestrial Acidification & TA & $1-2 \%$ & $10-20 \%$ & $2-3 \%$ & $11-22 \%$ \\
Freshwater Eutrophication & FE & $1-3 \%$ & $9-19 \%$ & $1-3 \%$ & $15-31 \%$ \\
Marine Eutrophication & ME & $1 \%$ & $3-5 \%$ & $0-1 \%$ & $10-21 \%$ \\
Terrestrial Ecotoxicity & TET & $1-2 \%$ & $8-15 \%$ & $1-2 \%$ & $19-37 \%$ \\
Freshwater Ecotoxicity & FET & $0 \%$ & $0-1 \%$ & $0 \%$ & $10-19 \%$ \\
Marine Ecotoxicity & MET & $0 \%$ & $0 \%$ & $0 \%$ & $10-20 \%$ \\
Agricultural Land Occupation & ALO & $1 \%$ & $5-10 \%$ & $1-2 \%$ & $17-34 \%$ \\
Urban Land Occupation & ULO & $1-2 \%$ & $6-12 \%$ & $1-3 \%$ & $13-25 \%$ \\
Natural Land Transformation & NLT & $1-3 \%$ & $11-23 \%$ & $1-3 \%$ & $16-31 \%$ \\
Metal Depletion & MD & $1 \%$ & $4-8 \%$ & $2-3 \%$ & $16-32 \%$ \\
Fossil Depletion & FD & $1-2 \%$ & $5-9 \%$ & $1 \%$ & $6-13 \%$ \\
\hline
\end{tabular}


Table 5. Changes in parameters observed on the sensitivity analysis for the variation of lubricant oil in the "empty" LOPCs.

\begin{tabular}{cccccc}
\hline Impact Categories & Abbr. & Scenario 0 & Scenario 1 & Scenario 2 & Scenario 3 \\
\hline Climate change & CC & $\pm 3 \%$ & $0-2 \%$ & $\pm 2 \%$ & $\pm 0 \%$ \\
Ozone depletion & OD & $\pm 19 \%$ & $\pm 13 \%$ & $\pm 16 \%$ & $\pm 0 \%$ \\
Human toxicity & HT & $0 \%$ & $\pm 0 \%$ & $0 \%$ & $\pm 0 \%$ \\
Photochemical oxidant formation & POF & $\pm 9 \%$ & $\pm 4 \%$ & $\pm 5 \%$ & $\pm 0 \%$ \\
Particulate matter formation & PMF & $\pm 8 \%$ & $\pm 4 \%$ & $\pm 5 \%$ & $\pm 0 \%$ \\
Ionising radiation & IR & $\pm 2 \%$ & $\pm 1 \%$ & $\pm 1 \%$ & $\pm 0 \%$ \\
Terrestrial acidification & TA & $\pm 12 \%$ & $\pm 6 \%$ & $\pm 8 \%$ & $\pm 0 \%$ \\
Freshwater eutrophication & FE & $\pm 4 \%$ & $\pm 2 \%$ & $\pm 2 \%$ & $\pm 0 \%$ \\
Marine eutrophication & ME & $\pm 2 \%$ & $\pm 1 \%$ & $\pm 1 \%$ & $\pm 1 \%$ \\
Terrestrial ecotoxicity & TET & $\pm 5 \%$ & $\pm 3 \%$ & $\pm 3 \%$ & $\pm 0 \%$ \\
Freshwater ecotoxicity & FET & $0-1 \%$ & $\pm 0 \%$ & $0 \%$ & $\pm 0 \%$ \\
Marine ecotoxicity & MET & $\pm 0 \%$ & $\pm 0 \%$ & $0 \%$ & $\pm 0 \%$ \\
Agricultural land occupation & ALO & $\pm 1 \%$ & $\pm 0 \%$ & $0 \%$ & $\pm 1 \%$ \\
Urban land occupation & ULO & $\pm 8 \%$ & $\pm 5 \%$ & $\pm 6 \%$ & $\pm 0 \%$ \\
Natural land transformation & NLT & $\pm 9 \%$ & $\pm 5 \%$ & $\pm 6 \%$ & $\pm 1 \%$ \\
Metal depletion & MD & $\pm 1 \%$ & $\pm 1 \%$ & $\pm 1 \%$ & $\pm 0 \%$ \\
Fossil depletion & FD & $\pm 18 \%$ & $\pm 12 \%$ & $\pm 15 \%$ & $\pm 1 \%$ \\
\hline
\end{tabular}

\section{Discussion and Conclusions}

As it normally occurs in a life cycle assessment, the most difficult part has been the collection of reliable data. Especially when dealing with companies, the data provided may not be trustworthy as they tend to "improve" reality. Sometimes, information from international databases was used to overcome this problem.

This study shows that fewer impacts are produced during the life cycle of lubricant oil plastic containers if destination to industrial landfills can be avoided. Scenarios with higher recycling rates and incineration as an alternative treatment option for LOPCs have proved to be the ones that caused lower overall environmental impacts. This is clearly visible in Figure 2, but the burdens avoided from the different scenarios are only visible in Figures 3-6.

Despite the fact that waste-to-energy is not a technology currently applied in Brazil for the treatment of LOPCs and that the analysis of its use has uncertainties due to the scarcity of primary data, it shows promising results as a substitute option for the destination of LOPCs, though further studies should be conducted to ascertain its merits.

One of the improvements that the Instituto Jogue Limpo could apply is an increase in the number of collection center units, thus shortening driving distances, thus reducing transportation costs and environmental impacts.

Furthermore, as the demand for the collection of used LOPCs rises, there should be more recycling plants associated with the program. For several years, the Instituto has sent the trimmed HDPE to recycling plants in other states, such as Minas Gerais and São Paulo, more than $400 \mathrm{~km}$ away from Rio de Janeiro, which has led to more use of diesel, therefore increasing the negative impacts of the whole chain.

The expansion of the Instituto Jogue Limpo to other regions in order to cover the whole country (currently it comprises only 15 of the 27 Brazilian states) would be an important step in improving waste management in Brazil, both by diverting LOPCs from landfills and by reducing the production of virgin plastics. It could enhance the program in the states in which it has already been implemented, expanding collection and recycling a larger share of used LOPCs. Finally, the Institute could also try to sell the recycled plastic back to the producers of LOPCs, transforming the process, or at least part of it, into a closed-loop one.

The Brazilian Government could consider further policy measures such as financial incentives and tax cuts to plastic recyclers and resellers of recycled material, inducing price reductions to make 
recycled products more appealing and competitive in the market. This initiative would work as an example for other sectors to invest in reverse logistic systems to assure correct reuse, recycling and/or disposal of post-consumption waste.

It must be stressed that although improvements and expansions are needed, important steps have already been taken to manage the hazard waste represented by LOPCs in Brazil. It has been shown that recycling can effectively mitigate environmental impacts, as it deviates waste from landfills, and that incineration can be an appealing destination option for plastic waste, especially hazardous waste. Additionally, this study shows that different destination options can be combined, depending on economic, logistical, and environmental considerations.

Finally, using a case study in a Brazilian state, this paper shows that emerging countries can deal with hazardous waste effectively. However, it takes time, political determination and adequate legislation, together with a cooperative posture of the private sector to accomplish desired results. Furthermore, the implementation of environmental management policies needs inputs provided by solid technical studies, such as the ones provided by the LCA methodology, to enable the finding of the best possible solutions.

Acknowledgments: This work was accomplished with financial support from Conselho Nacional de Desenvolvimento Científico e Tecnológico (CNPq).

Author Contributions: Maria Clara Oliveira and Alessandra Magrini conceived and designed the experiments; Maria Clara Oliveira performed the experiments, analyzed the data and wrote the paper; Alessandra Magrini contributed with the analysis tools and revised the paper.

Conflicts of Interest: The authors declare no conflict of interest. The founding sponsors had no role in the design of the study; in the collection, analyses, or interpretation of data; in the writing of the manuscript, and in the decision to publish the results.

\section{References}

1. Denatran. Departamento Nacional de Trânsito. Available online: http://www.denatran.gov.br/index.php/ estatistica/253-frota-2014 (accessed on 4 April 2016).

2. Aguiar, A.O.; Joaquim Filho, J. Veículos em Fim de Vida Como Resíduos: Panorama, Fragilidades e Perspectivas do Gerenciamento No Brasil. Simpoi. 15. 2012. Available online: http://www.simpoi. fgvsp.br/arquivo/2012/artigos/E2012_T00377_PCN71573.pdf (accessed on 12 September 2016).

3. United States Environmental Protection Agency (EPA). Plastic Oil Bottle Recycling. Final Report. 2006. Available online: https://cfpub.epa.gov/ncer_abstracts/index.cfm/fuseaction/display.highlight/abstract/ 7974/report/F (accessed on 10 December 2016).

4. Monier, V.; Labouze, E.; Sofres, T.N. Critical Review of Existing Studies and Life Cycle Analysis on the Regeneration and Incineration of Waste Oils. European Commission. Available online: http:/ /ec.europa.eu/ environment/waste/studies/oil/waste_oil.htm (accessed on 10 July 2016).

5. United Nations Environment Programme (UNEP). Compendium of Recycling and Destruction Technologies for Waste Oils; IETC: Osaka, Japan, 2012.

6. Associação Brasileira de Normas Técnicas (ABNT). NBR 10004: Classificação de Resíduos Sólidos; ABNT: Rio de Janeiro, Brazil, 2004.

7. Intergovernmental Panel on Climate Change (IPCC). Good Practice Guidance and Uncertainty Management in National Greenhouse Gas Inventories. Report. 2001. Available online: http:/ / www.ipcc-nggip.iges.or.jp/ public/gp/bgp/5_3_Waste_Incineration.pdf (accessed on 10 December 2016).

8. Willing, A. Lubricants based on renewable resources-An environmentally compatible alternative to mineral oil products. Chemosphere 2001, 43, 89-98. [CrossRef]

9. PlasticsEurope. Plastics-The Facts 2014/2015-An Analysis on European Plastics Production, Demand and Waste Data; PlasticsEurope: Brussels, Belgium, 2015; Available online: http://issuu.com/plasticseuropeebook/ docs/final_plastics_the_facts_2014_19122 (accessed on 15 July 2016).

10. Plastivida. Monitoramento dos Î́ndices de Reciclagem Mecânica de Plástico No Brasil (IRmP). 2011. Available online: http:/ / www.plastivida.org.br/images/temas/Apresentacao_IRMP2011.pdf (accessed on 25 November 2015). 
11. Sindicom. Data for the Lubricant Oil Sector. 2016. Available online: http://www.sindicom.com.br/ \#conteudo.asp?conteudo=72\&id_pai=60\&targetElement=leftpart (accessed on 9 December 2016).

12. Freitas, E. Embalagens Plásticas de Óleo Lubrificante. Programa Jogue Limpo. Congresso Nacional Simepetro. 4. 2011. Available online: http://www.simepetro.com.br/wp-content/uploads/SINDICOM1. pdf (accessed on 12 May 2015).

13. Demertzi, M.; Dias, A.C.; Matos, A.; Arroja, L.M. Evaluation of different end-of-life management alternatives for used natural cork stoppers through life cycle assessment. Waste Manag. 2015, 46, 668-680. [CrossRef]

14. Sistema Firjan. Manual de Gerenciamento de Resíduos: Guia de Procedimento Passo a Passo, 2nd Edição. Available online: http://www.firjan.com.br/lumis/portal/file/fileDownload.jsp?fileId= 2C908A8F4EBC426A014ED041F0FB576E\&inline=1 (accessed on 10 August 2015).

15. Lovón-Canchumani, G.A. Óleos Lubrificantes Usados: Um Estudo de Caso de Avaliação de Ciclo de Vida do Sistema de Rerrefino no Brasil; Tese de Doutorado, Universidade Federal do Rio de Janeiro, Programa de Planejamento Energético PPE/COPPE/UFRJ: Rio de Janeiro, Brazil, 2013.

16. European Commission. Directive 2008/98/EC of the European Parliament and of the Council of 19 November 2008 on Waste and Repealing Certain Directives; Publications Office of the European Union: Luxemburg, 2008.

17. Pires, A.; Martinho, G.; Chang, N.-B. Solid waste management in European countries: A review of systems analysis techniques. J. Environ. Manag. 2011, 92, 1033-1050. [CrossRef] [PubMed]

18. Kanokkantapong, V.; Kiatkittipong, W.; Panyapinyopol, B.; Wongsuchoto, P.; Pavasant, P. Used lubricating oil management options based on life cycle thinking. Resour. Conserv. Recycl. 2009, 53, 294-299. [CrossRef]

19. Boughton, B.; Horvath, A. Environmental assessment of used oil management methods. Environ. Sci. Technol. 2004, 38, 353-358. [CrossRef]

20. European Comission. Plastic and Packaging Waste Directive (94/62/EC): European Parliament and Council Directive 94/62/EC of 20 December 1994 on Plastic and Packaging Waste. Available online: http:/ / eur-lex. europa.eu/legal-content/EN/TXT/?uri=CELEX:01994L0062-20150526 (accessed on 20 October 2016).

21. Resource Conservation and Recovery Act of 1976, Pub. L. No. 94-580, Oct. 21, 1976, 90 Stat. 2795 (to Be Codified as 42 U.S.C $\$ \S 6901-87)$. Available online: https:/ /www.epa.gov/laws-regulations/summaryresource-conservation-and-recovery-act (accessed on 15 December 2016).

22. Brasil. Lei Federal $N^{\circ}$ 12.305, “Institui a Política Nacional de Resíduos Sólidos; Altera a lei $\mathrm{n}^{\circ}$ 9.605, de 12 de Fevereiro de 1998; e dá Outras Providências", Brasil, 2 de Agosto de 2010. Available online: http:/ / www.planalto.gov.br/ccivil_03/_ato2007-2010/2010/lei/112305.htm (accessed on 3 March 2017).

23. Murphy, P.R.; Poist, R.P. Managing of logistics retro movements: An empirical analysis of literature suggestions. Transp. Res. Forum 1989, 29, 177-184.

24. Carter, C.R.; Ellram, L.M. Reverse logistics: A review of the literature and framework for future investigation. J. Bus. Logist. 1998, 19, 85-102.

25. Stock, J.R. Development and Implementation of Reverse Logistics Program; Council of Logistics Management: Oak Brook, IL, USA, 1998.

26. Dowlatshahi, S. Developing a theory of reverse logistics. Interfaces 2000, 30, 143-155. [CrossRef]

27. Srivastava, S. Network design for reverse logistics. Omega 2008, 36, 535-548. [CrossRef]

28. Rogers, D.S.; Tibben-Lembke, R. Going Backwards: Reverse Logistics Trends and Practices; Full Report; Reverse Logistics Executive Council: Reno, NV, USA, 1998.

29. Pokharel, S.; Mutha, A. Perspectives in reverse logistics: A review. Resour. Conserv. Recycl. 2009, 53, $175-182$. [CrossRef]

30. Agrawal, S.; Singh, R.K.; Murtaza, Q. A literature review and perspectives in reverse logistics. Resour. Recycl. Conserv. 2015, 97, 76-92. [CrossRef]

31. Jogue Limpo. Available online: www.joguelimpo.org.br (accessed on 12 July 2016).

32. Veiga, M.M. Analysis of efficiency of waste reverse logistics for recycling. Waste Manag. Res. 2013, 31, 26-34. [CrossRef] [PubMed]

33. Friege, H.; Fendel, A. Competition of different methods for recovering energy from waste. Waste Manag. Res. 2011, 29, 30-38. [CrossRef] [PubMed]

34. Meneses, M.; Schuhmachera, M.; Domingo, J.L. Health risk assessment of emissions of dioxins and furans from a municipal waste incinerator: Comparison with other emission sources. Environ. Int. 2004, 30, 481-489. [CrossRef] [PubMed] 
35. Morselli, L.; Passarini, F.; Piccari, L.; Vassura, I.; Bernardi, E. Risk assessment applied to air emissions from a medium-sized Italian MSW incinerator. Waste Manag. Res. 2011, 29, 48-56. [CrossRef] [PubMed]

36. Finkbeiner, M.; Schau, E.M.; Lehmann, A.; Traverso, M. Towards life cycle sustainability assessment. Sustainability 2010, 2, 3309-3322. [CrossRef]

37. Guinée, J.B.; Heijungs, H.; Huppes, G.; Zamagni, A.; Masoni, P.; Buonamici, R.; Ekvall, T.; Rydberg, T. Life cycle assessment: Past, present, and future. Environ. Sci. Technol. 2011, 45, 90-96. [CrossRef] [PubMed]

38. Lorenz, E. Life-cycle assessment in US codes and standards. PCI J. 2014, 59, 49-54.

39. Rigamonti, L.; Grosso, M.; Giugliano, M. Life cycle assessment of sub-units composing a MSW management system. J. Clean. Prod. 2010, 18, 1652-1662. [CrossRef]

40. International Standards Organization. ISO 14040 Environmental Management Life Cycle Assessment Principles and Framework; International Standards Organization: Brussels, Belgium, 2006.

41. ISO 14044 Environmental Management Life Cycle Assessment Requirements and Guidelines; International Stardard Organization: Brussels, Belgium, 2006.

42. Guinée, J.B.; Gorrée, M.; Heijungs, R.; Huppes, G.; Kleijn, R.; de Koning, A.; van Oers, L.; Wegener Sleeswijk, A.; Suh, S.; Udo de Haes, H.A.; et al. Handbook on Life Cycle Assessment: Operational Guide to the ISO Standards, 1st ed.; Springer: Dordrecht, The Netherlands, 2002; 692p.

43. European Comission. International Reference Life Cycle Data System (ILCD) Handbook-General Guide for Life Cycle Assessment-Detailed Guidance, 1st ed.; Publications Office of the European Union, Joint Research Centre, Institute for Environment and Sustainability: Ispra, Italy, 2010; 417p.

44. Bousted Consulting and Associates Ltd. Life Cycle Assessment for Three Types of Grocery Bags-Recyclable Plastic. Compostable, Biodegradable Plastic, and Recycled, Recyclable Paper. 2007. Available online: https:// plastics.americanchemistry.com/Life-Cycle-Assessment-for-Three-Types-of-Grocery-Bags.pdf (accessed on 10 January 2016).

45. Siracusa, V.; Ingrao, C.; Giudice, A.L.; Mbohwa, C.; Dalla Rosa, M. Environmental assessment of a multilayer polymer bag for food packaging and preservation: An LCA approach. Food Res. Int. 2014, 62, 151-161. [CrossRef]

46. Accorsi, R.; Versari, L.; Manzini, R. Glass vs. plastic: Life cycle assessment of extra-virgin olive oil bottles across global supply chains. Sustainability 2015, 7, 2818-2840. [CrossRef]

47. Baitz, M.; Kreißig, J.; Byrne, E.; Makishi, C.; Kupfer, T.; Frees, N.; Bey, N.; Hansen, M.S.; Hansen, A.; Bosch, T.; et al. Life Cycle Assessment of PVC and of Principal Competing Materials. 2004. Available online: http://www.pvc.org/upload/documents/PVC-final-report-lca.pdf (accessed on 4 November 2015).

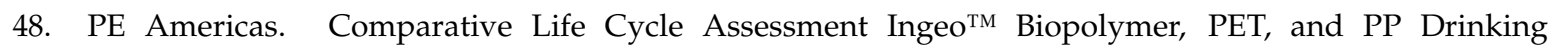
Cups for Starbucks Coffee Company and Nature Works LLC. Full Report. 2009. Available online: http://www.natureworksllc.com/ /media/The_Ingeo_Journey/EcoProfile_LCA/LCA/PEA_Cup_Lid_ LCA_FullReport_ReviewStatement_121209_pdf.pdf (accessed on 14 June 2016).

49. Lehmann, B.; Vilaplana, F.; Strömberg, E.; Suliman, W.; Cerrato, L.R. Comparative LCA on Plastic Packaging; Report. 2005. Available online: http:/ /www.lcm2007.org/paper/168.pdf (accessed on 4 April 2016).

50. LCA of Management Options for Mixed Waste Plastics. 2008. Available online: http://www.wrap.org. uk/sites/files/wrap/LCA\%20of\%20Management\%20Options\%20for\%20Mixed\%20Waste\%20Plastics.pdf (accessed on 18 November 2016).

51. Perugini, F.; Mastellone, M.L.; Arena, U. A life Cycle assessment of mechanical and feedstock recycling options for management of plastic packaging wastes. Environ. Prog. 2005, 24, 137-154. [CrossRef]

52. Ferreira, S.; Cabral, M.; da Cruz, N.F.; Simões, P.; Marques, R.C. Life cycle assessment of a packaging waste recycling system in Portugal. Waste Manag. 2014, 34, 1725-1735. [CrossRef] [PubMed]

53. Instituto Brasileiro de Geografia e Estatística (IBGE). 2016. Available online: http:/ / cod.ibge.gov.br/7DM (accessed on 17 October 2016).

54. Becker, H.S. Métodos de Pesquisa em Ciências Sociais; HUCITEC: São Paulo, Brazil, 1997.

55. Willers, C.D.; Rodrigues, L.B. A critical evaluation of Brazilian life cycle assessment studies. Int. J. Life Cycle Assess. 2014, 19, 144-152. [CrossRef]

56. Zanghelini, G.M.; de Souza, H.R.A., Jr.; Kulay, L.; Cherubini, E.; Ribeiro, P.T.; Soares, S.R. A bibliometric overview of Brazilian LCA research. Int. J. Life Cycle Assess. 2016, 21, 1759-1775. [CrossRef] 
57. Syke. Reducing Greenhouse Gas Emissions by Recycling Plastics or Textile Waste? Finnish Environment Institute: Helsinki, Finland, 2007; Available online: http://www.iswa.org/uploads/tx_iswaknowledgebase/620121_ Paper.pdf (accessed on 16 December 2016).

58. Instituto Brasileiro de Informação em Ciência e Tecnologia (IBICT). Banco nacional de Inventários de Ciclo de Vida. 2016. Available online: http:/ / sicv.acv.ibict.br/Node/ (accessed on 16 September 2016).

59. Indaver. Sustainability Report. 2014. Available online: http://www.indaver.nl/fileadmin/indaver/ Publications/Sust\%20report/SR_2014_EN_FINAL.pdf (accessed on 7 March 2017).

60. Ecoinvent Center. Ecoinvent Data v3.0. Swiss Centre for Life Cycle Inventories, St. Gallen. Available online: www.ecoinvent.org (accessed on 15 September 2016).

61. Ministério do Meio Ambiente (MMA). $1^{\circ}$ Inventário Nacional de Emissões Atmosféricas por Veículos Automotores Rodoviários. Relatório Final. 2011. Available online: http:/ /www.mma.gov.br/estruturas / 163/_publicacao/163_publicacao27072011055200.pdf (accessed on 17 October 2016).

62. Petro-Canada. Petro-Canada Lubricants Handbook. 2016. Available online: http://lubricants.petro-canada. ca/en-CA/ (accessed on 7 October 2016).

63. Goedkoop, M.; Heijungs, R.; Huijbregts, M.; Schryver, A.D.; Struijs, J.; van Zelm, R. ReCiPe 2008-A Life Cycle Impact Assessment Method Which Comprises Harmonised Category Indicators at the Midpoint and the Endpoint Level. Available online: http://www.leidenuniv.nl/cml/ssp/publications/recipe_ characterisation.pdf (accessed on 15 April 2016).

64. Prè-Sustainability. Simapro. Available online: http://www.pre-sustainability.com/simapro-lca-software (accessed on 1 March 2017).

65. European Comission. International Reference Life Cycle Data System (ILCD) Analysis of Existing Environmental Impact Assessment Methodologies for Use in Life Cycle Assessment, 1st ed.; Publications Office of the European Union, Joint Research Centre, Institute for Environment and Sustainability: Ispra, Italy, 2010; 417p.

66. Sleeswijk, A.W.; van Oers, L.F.; Guinèe, J.B.; Struijs, J.; Huijbregts, M.A. Normalization in product life cycle assessment: An LCA of the global and European economic systems in the year 2000. Sci. Total Environ. 2008, 390, 227-270. [CrossRef] [PubMed]

(C) 2017 by the authors. Licensee MDPI, Basel, Switzerland. This article is an open access article distributed under the terms and conditions of the Creative Commons Attribution (CC BY) license (http:/ / creativecommons.org/licenses/by/4.0/). 